\title{
DAIRY BUFFALO PRODUCTION SYSTEM UNDER SEMI-INTENSIVE MANAGEMENT IN THE COASTAL AREA OF BANGLADESH
}

\author{
S.M.R. Rahman", M.N. Islam, M.H. Rashid, M.S.R. Siddiki and M.A. Islam \\ Department of Dairy Science, Bangladesh Agricultural University, Mymensingh 2202, Bangladesh
}

\begin{abstract}
This study was conducted to evaluate the present status of production system of dairy buffalo under semi-intensive management in coastal area of Bangladesh. The data were collected during farm visit and recorded in prepared questionnaire and check list. The findings of the study revealed that very minimum housing facilities were provided to the buffaloes. Both the grazing and confinement time were found similar (around $6 \mathrm{hrs}$ in a day) and they spent almost $3 \mathrm{hrs}$ in a day for wallowing. The majority of the lactating buffaloes were not being adequately fed. Farmers usually supplied local grass $(4.98 \pm 2.89 \mathrm{~kg}$ $\mathrm{DM} /$ day) and rice straw (10.90 $\pm 2.85 \mathrm{~kg} \mathrm{DM} /$ day) with one or two concentrate feed separately as supplement $(1.51 \pm 0.80 \mathrm{~kg} \mathrm{DM} /$ day). The daily average DCP and TDN supply were 0.365 and $6.417 \mathrm{~kg} / \mathrm{d}$ respectively which were undersupplied as compared to standard requirement. The productive and reproductive performance of indigenous dairy buffalo was not similar to high producing dairy buffaloes. The average lactation yields (litre/lactation) were found as $469.52 \pm 163.71$. The EC value $(2.73 \pm 3.53)$ of milk indicated as healthy milk production. Milk consumption pattern (8\%) was not satisfactory. Milk market was volatile. Natural breeding $(95.7 \%)$ was more prominent practice than artificial insemination (Al) (4.3\%). The most of the buffalo cows showed heat from early night to early morning (22.2-54.2\%). Technology adaptation for buffalo rearing was very much poor. Technology adaptation index for the use of concentrate feed, artificial insemination, de-worming and vitamin-mineral premix were 16.34, 13.46, 23.07 and 6.25 respectively. It therefore be concluded that technological transformation could be boost up to national milk production by developing of the management practise of dairy buffalo under semiintensive system in Bangladesh.
\end{abstract}

Keywords: Dairy buffalo, semi-intensive, management practice, coastal area, technology

\footnotetext{
* Corresponding author: smrajiurrahman@yahoo.com
} 
S.M.R. Rahman et al.

\section{INTRODUCTION}

The dynamics of buffalo production systems in South Asia Region is transforming day by day due to increasing the population more rapidly specially in Asia for its emerging role in economic development (Dhanda, 2013). Buffalo production system varies widely in accordance with climate, soil and socio economic opportunities in Bangladesh (Saadullah, 2012). Buffalos graze in natural pasture in coastal areas. A total of 11,5 and $84 \%$ farmers reared buffalo for milk purpose, meat purpose and milk and meat purpose, respectively in coastal areas (Nahar et al., 2014). According to Saadullah (2012) buffaloes are kept mainly for specific purposes, i.e. either for milk or for meat production in Bangladesh under semi intensive system. It is an important livestock resource in several countries of South Asia and the Mediterranean regions. Buffalo is playing a leading role in the national economy by producing milk, meat and draught power in India and Pakistan. Buffalo contributes about $57 \%$ and $68 \%$ of total milk production of India and Pakistan, respectively (FAO, 2010). Due to high fat content of buffalo milk, it is the most preferred species and called Black gold of Pakistan (Bilal et al., 2006). Climatic condition of Bangladesh is nearly similar to India and has many rivers and marshy lands that favour for raising buffaloes. Recently Government of Bangladesh, private sector and research organization has given emphasis on Buffalo production. The availability of milk in Bangladesh is only about $158.19 \mathrm{ml} \mathrm{h}^{-1} \mathrm{~d}^{-1}$ of about $63.27 \%$ (DLS, 2018) whereas, the availability of milk in India and Pakistan is about $290 \mathrm{ml}, 525 \mathrm{ml}, \mathrm{h}^{-1} \mathrm{~d}^{-}$ ${ }^{1}$, respectively (Hamid et al.,2016). This figure indicates that Bangladesh need to give more emphasis on the milk production to fulfil the national demand. The indigenous dairy cows are low producers and the crossbred cow has the limitation regarding disease resistance, repeat breeding etc. Use of other mammalian livestock species for milk production could help to improve the scenario (Siddiki, 2017) and the success of India and Pakistan dairy industry based on buffalo might be a good example for Bangladesh. However, buffaloes are low producers in Bangladesh, because of poor genetic potentialities, poor nutrition, longer puberty age, seasonality of breeding, longer calving interval, high calf mortality and poor management practices (Nahar, 2015;Amin et al.,2015; Sarker et al., 2013; Faruque and Amin, 1995; Shamsuddin et al., 2001). Faruque and Amin (1995), Uddin et al., (2016) and Amin et al., (2017) reported the management and production performances of buffaloes of Noakhali district of Bangladesh. However, there is no report on the management and production performances of buffaloes of Bhola district in Bangladesh which possesses the highest number of buffaloes of the country. Moreover different management system e.g. extensive and semi-intensive systems were followed in this area. Semi-intensive system introduces very recently for emphasised lactating buffaloes. Therefore, the present study was designed to investigate the existing management system along with reproduction and production characteristics of dairy buffalo in Bhola district of Bangladesh under semi-intensive system. 


\section{MATERIALS AND METHODS}

\section{Location of study areas}

The study area was Vhalu Miar Char, Sub-district: Bhola sadar, District: Bhola (AEZ18 , coastal area), Bangladesh. This is a coastal area of Bangladesh having high buffalo concentration (10.1-32.3 buffaloes/1000 people (Huque and Khan, 2017).Under the Köppen Climate Classification, Bhola is under Tropical Monsoon Climate (Wikipedia, 2017). General information of study area demonstrated in Table 1.

Table 1. General information and satellite image of study area

$\begin{array}{ll}\begin{array}{l}\text { The Köppen Climate } \\ \text { Classification }\end{array} & \begin{array}{l}\text { Tropical wet } \\ \text { climate (Aw) }\end{array} \\ \begin{array}{l}22.6903^{\circ} \mathrm{N} \& \\ \text { Bhocation Vhalu Miar Char, }\end{array} & 90.6525^{\circ} \mathrm{E} \\ \text { Temperature (Min-Max) } & 19-29^{\circ} \mathrm{C} \\ \text { Humidity (\%) } & 71 \\ \text { Average yearly rain fall(mm) } & 2424 \\ \text { Human population density } & 480 / \mathrm{km} 2 \\ \text { Management system } & \text { Semi-intensive } \\ \text { Breed type } & \text { Indigenous }\end{array}$

Source: https://en.wikipedia.org; https://www.timeanddate.com/weather/@ 1336136/climate ;https://www.banglapedia.org

\section{Farmer selection}

Buffalo farmers were randomly selected from three villages. Farmers had at least one milking buffalo with calf and reared buffalo under semi-intensive management system. Farm visit, farm observation, secondary review, community discussion were held in the from January to July 2017.

\section{Preparation of questioner}

Structured questionnaire was developed according to variable of the objectives. Variables like productive and reproductive performances, feeding and management practices with related problem for buffalo farming were considered. The questionnaire was pre-tested in the selected area. The preliminary schedule was edited on the basis of experience gained in pre-testing and then the questionnaire was finalized. The schedule contains both open and closed-ended question. 
S.M.R. Rahman et al.

\section{Data collection}

Qualitative and quantitative information were collected from semi-intensive farm. Data were collected directly from 30 farms by the experience enumerators. Researcher monitored the enumerators and support as required by direct visit and mobile communication. Moreover, more than 40 milking buffalo farmers were directly contacted by the researcher for validation of the information. Discussion was also conducted with the cowboys (hired labours) who are responsible for the care and management of the buffalo and the farm as a whole, to confirm and recheck the information that were collected from the household buffalo farms which fulfil the triangulation methods.

\section{Period of Study}

Farm visit, farm observation, secondary review, community discussion were held in the period of six moths which was from January to July 2017.

\section{Sample collection and analysis}

Information regarding the amount and types of feeds and fodders being offered randomly to thirty the lactating buffaloes. The quantity of dry matter (DM), digestible crud protein (DCP) and total digestible nutrient (TDN) available to dairy buffaloes were calculated from the records of feeds and fodder using value as given by Kearl (1982) and Feedipidia.org (2018). Their requirements for DCP and TDN were worked out according to Kearl (1982).

During this visit, 15 individual milk samples (50 ml/sample) were also collected from study area. The milk samples were immediately placed in a home freezer, transported in a cool box and again placed in a regular freezer in the Dairy Chemistry Laboratory, Department of Dairy Science, Bangladesh Agricultural University, Mymensingh-2202, Bangladesh until further analyses. Milk samples were analyzed for fat, protein, lactose, SNF, ash content and Electric Conductivity (EC) by automilk analyzer (Lactoscan, Ultrasonic Milk Analyzer; Model MIA-SLP-60, S/N70148; MILKOTONIC Ltd., Bulgaria 6000. Stara zagora).

\section{Data Analysis}

After collecting data from field, these were edited and coded. The data was then transfer to MS Excel 2007 for processing and summarizing. The tabular technique mainly used to analyze the data and derived meaningful finding by using simple statistical measures like mean, percentage and ratio by using SPSS16 version.

\section{RESULTS AND DISCUSSION}

\section{Buffalo herd composition}

Farmers kept different type of buffalo in the herd. The average herd size was found to be $1.80 \pm 0.12$. The herd was composed mainly of lactating buffalo, dry buffalo, buffalo heifer, buffalo bull and buffalo calf. The average number of lactating 
buffalo, dry buffalo, buffalo heifer, buffalo bull and buffalo calf were $1.01 \pm 1.01$, $0.78 \pm 1.72,0.89 \pm 1.85,1.06 \pm 1.62$ and $1.02 \pm 1.94$, respectively under semi-intensive system (Table 2 and Figure 1). This result supports to the findings of Uddin et al., (2016) who reported that $82 \%$ of the farmers having 1 to 3 buffalo reared under semi intensive system in coastal areas of Bangladesh. However Huque and Borghese (2013) found that average herd size in household subsistence farming (HF) and semiintensive farming (SIF) buffaloes were about 1-3 and 4-15, respectively. Faruque (2000) found that the percentage of milking buffaloes, dry buffaloes, heifer buffaloes, bulls and calves were 35,15,16, 2 and 32, respectively in the upper part of coastal area reared under semi intensive management system which is very similar of our finding though number of bulls were relatively few in his study. But Akbar et al., (2009) mentioned that there was sufficient number of bull for breeding purpose in coastal areas.

Table 2. Average number of buffalo holding under semi-intensive system in Bhola district

\begin{tabular}{llll}
\hline Type of buffalo & Mean \pm SD $(\mathrm{N})$ & Min & Max \\
\hline $\begin{array}{l}\text { Lactating Buffalo } \\
\text { (No/HH) }\end{array}$ & $\begin{array}{l}1.85 \pm 1.01 \\
(39)\end{array}$ & 1 & 4 \\
$\begin{array}{l}\text { Dry } \\
\text { Buffalo(No/HH) }\end{array}$ & $1.72 \pm 0.78(19)$ & 1 & 3 \\
$\begin{array}{l}\text { Heifer } \\
\text { Buffalo(No/HH) }\end{array}$ & $1.8 \pm 0.89(13)$ & 1 & 3 \\
$\begin{array}{l}\text { Buffalo Bull } \\
\text { No/HH) }\end{array}$ & $1.62 \pm 1.06(13)$ & 1 & 4 \\
$\begin{array}{l}\text { Buffalo calf } \\
\text { No/HH) }\end{array}$ & $1.94 \pm 1.02(37)$ & 1 & 4 \\
Overall & $1.80 \pm 0.12$ & \\
\hline \begin{tabular}{l} 
NoNumber of obst \\
\hline
\end{tabular}
\end{tabular}

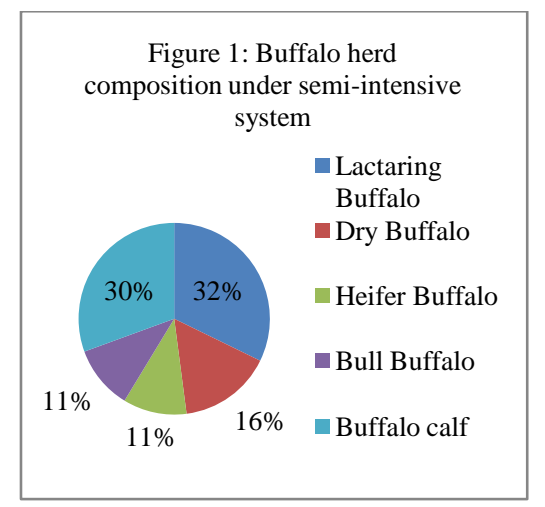

$\mathrm{N}_{\overline{7}}=$ Number of observation; $\mathrm{SD}_{\overline{;}}=$ Standard Deviation

\section{Housing system of buffalo}

Different types of housing were seen in the study area. Some farmers' constructed floor by brick, some sheds have roofs using tin or golpata (Nipa fruticans). Most of the house had no boundary wall and roof. Many buffaloes were kept on raised place in the open yard at day-night. Uddin et al., (2016) observed that dairy buffaloes were kept under semi-intensive system in the wet season and only $15 \%$ farmers provided shed having only roof but no concrete floor. Akbar et al., (2009) mentioned that most of the dairy buffalo were not housed in extensive system of bathan areas but buffaloes which were in the plain land sometime had an enclosure with only roof 
made by straw or tin without wall and floor was always muddy. The average grazing time of buffalo was $6.04 \pm 1.52$ hour in a day and rest of the time $(5.91 \pm 1.70$ hour/day) it was kept in confinement shed situated in household yard (Table 3). The average wallowing time of buffalo was found 2.78 \pm 1.34 hour/day (Table 3). Saadullah (2012) described that the buffalo farmers had their own wallowing place, but sometimes the whole village herd down together in mud wallows. Siddiki (2017) noted that majority $(85 \%)$ of the buffalo farmers followed average grazing period of 6-8 $\mathrm{h}$ in a day and lowest grazing period $(<6 \mathrm{~h})$ was found in Trishal and Lalpur Upozila $(10 \%)$ which was similar to our findings.

Table 3. Average scavenges confinement and wallowing time (hrs/day)

\begin{tabular}{llll}
\hline Variable & Mean \pm SD & Minimum & Maximum \\
\hline Grazing duration $\left(\right.$ hrs day $\left.^{-1}\right)$ & $6.04 \pm 1.52$ & 2 & 8 \\
Confinement $\left(\mathrm{hrs} \mathrm{day}^{-1}\right)$ & $5.91 \pm 1.70$ & 3 & 10 \\
Wallowing $\left(\right.$ hrs day $\left.^{-1}\right)$ & $2.78 \pm 1.34$ & 1 & 6 \\
\hline
\end{tabular}

\section{Feeding system}

The available feed stuff were straw e.g. paddy straw ( Oryza sativa); local green grass e.g. Dol (Saccrolepsis indica), Dubla (Cynodon dactylon), Halancha (Enhydra fluctuens), Sesbania, Water hyacinth (Eichhornia Crassipes) and kheshari (Lathyrus sativus); Concentrate feed e.g. oil cakes, wheat bran, rice polish, soybean meal and broken maize in the study area. Islam et al., (2002) identified more than fifty different types of local green grasses from different Agro Ecological Zones (AEZs) in Bangladesh among which most of those were same found in the present study. They noticed that baksha, lota, poa, khesari, beju, matikalai, kolmi, gamma, badam, durba, chailla, helencha, shama were mostly common and more potential native grasses. 89\%, 100\% and $57 \%$ farmers provided dry roughage (straw), green roughage (local grass) and concentrate feed respectively to lactating buffaloes under this system. Among those, the average dry roughage, green roughage and concentrate feed supply were $10.90 \pm 2.85,4.98 \pm 2.89$ and $1.51 \pm 0.80 \mathrm{Kg} \mathrm{DM}$ day $^{-1}$ head $^{-1}$, respectively. Nahar et al., (2015) found that 22 - 23\% farmers supplied only straw, $95.55 \%$ farmers supplied straw with roughages, $8.89 \%$ farmers supplied only concentrate under extensive system in Bhola district. In the Ganges-Brahmaputra flood plain, dairy buffaloes were reared in semi-intensive system in which farmer raised buffaloes with minimum inputs. They were allowed to graze on natural pasture or road side in day time and were corralled at night (Akbar et al., 2009). The household subsistence farming (HF) buffaloes were reared under stall feeding with 67 hours grazing around backyard or public land with very little feed supply. The semi-intensive farming (SIF) buffaloes were raised in combination of seasonal based 
household during rice cultivation and free range system during common land free which was mostly upper part of coastal areas (Huque and Borghese, 2013). According to investigation of Uddin et al., (2016), in the household farming, after morning milking, buffaloes were allowed to graze in fallow or road side land up to evening that covers approximately 8-9 hours per day. From the evening to next morning, buffaloes were tied up in homestead and they were offered mainly rice straw with little concentrate mixtures (wheat bran, rice bran, rice polish etc). The findings of the present study do not agree with the findings of Uddin et al., (2016) who mentioned the natural grass is the main source of feed in contrast to straw. This transforming perhaps to happen for newly introduces of semi-intensive system for lactating buffaloes in upper land of the coastal areas. Besides different crops were occupied most of the fellow land.

Table 5. Average feed supply (DM kg ${ }^{-1} \mathrm{day}^{-1} \mathrm{head}^{-1}$ ) of lactating buffalo under semiintensive system in Bhola district

\begin{tabular}{l|l|l|l}
\hline Items & Mean \pm SD & Minimum & Maximum \\
\hline Concentrate feed & $\begin{array}{l}1.51 \pm 0.80 \\
(57)\end{array}$ & 0.44 & 2.64 \\
Straw & $10.90 \pm 2.85(89)$ & 4.50 & 16.0 \\
Green grass (cut and carry ) & $4.98 \pm 2.89(100)$ & 1.6 & 11.30 \\
Total supply & $16.16 \pm 3.28$ & 6.4 & 20.3 \\
\hline
\end{tabular}

Figure parenthesis in the bracket indicates percentage of farmers

\section{Nutritional status}

Feeding practice deprives the potential high milk producers and also overburdens the low producers with nutrients (Habib et al., 2007). The average estimated levels of nutrients supplied to lactating buffaloes in coastal (Bhola) area of Bangladesh presented in Table 6.

Table 6. Average estimated levels of nutrients supplied to lactating buffaloes in coastal area in Bangladesh

\begin{tabular}{l|c|c|c}
\hline \multicolumn{1}{c|}{ Name of the feed resources } & $\begin{array}{c}\text { Amount } \\
\mathrm{DM}\left(\mathrm{kg} \mathrm{d}^{-1}\right)\end{array}$ & $\mathrm{DCP}\left(\mathrm{kg} \mathrm{d}^{-1}\right)$ & $\mathrm{TDN}\left(\mathrm{kg} \mathrm{d}^{-1}\right)$ \\
\hline Coastal area: Bhola & & & \\
i. Broken Maize(Zea mays) & 0.750 & 0.040 & 0.563 \\
ii. Soybean meal(Glycine maximum) & 0.560 & 0.228 & 0.459 \\
iii. Rice bran (Oryza sativa) & 0.200 & 0.015 & 0.120 \\
\hline
\end{tabular}




\begin{tabular}{l|c|c|c}
\hline Name of the feed resources & $\begin{array}{c}\text { Amount } \\
\text { DM (kg d-1) }\end{array}$ & $\begin{array}{c}\text { DCP(kg d- } \\
1)\end{array}$ & $\begin{array}{c}\text { TDN(kg d- } \\
1)\end{array}$ \\
\hline A. Total concentrate mixture (i+ii+iii) & 1.510 & 0.283 & 1.142 \\
B. Straw (Oryza sativa) & 10.900 & 0.022 & 4.578 \\
C. Grass (native mix) & 4.980 & 0.060 & 0.697 \\
D. Total(A+B+C) & 17.390 & 0.365 & 6.417 \\
\hline
\end{tabular}

Daily average digestible crude protein(DCP) supply in the lactating buffaloes in Bhola district were $364 \mathrm{~g} \mathrm{~d}^{-1}$ which were undersupplied as compared to requirement of Kearl (1982) standard (Table 7; Fig 2) considering average body weight $242.0 \pm 45.1$ and milk fat percent (7.3 \pm 2.66$)$. Other studies aimed at evaluating the nutritional status of dairy animals in India based on survey of different districts/regions showed variable trends-most of them showing undersupply of DCP as compared to standard requirements (Vidya et al., 2013; Bakshi et al., 2010; Jawale et al., 2007; Singh et al., 2003). These findings agreed with our observation. However daily average DCP intake in the buffaloes in Patan district of India was observed $1.049 \mathrm{~kg} \mathrm{~d}^{-1}$ that indicates the buffaloes got adequate DCP as per the requirement (Chavda and Parnerkar, 2016). Daily average total digestible nutrient (TDN) supply to the lactating buffaloes in Bhola areas of Bangladesh were observed $6.417 \mathrm{~kg} \mathrm{~d}^{-1}$ (Table 6) which indicated that the buffaloes got few amount of low TDN $(-0.353 \mathrm{~kg}$ $\mathrm{d}^{-1}$ ) than requirement of Kearl (1982) standard (Table 7; Fig 3). Chavda and Parnerkar (2016) got surplus amount of average TDN intake $\left(10.17 \mathrm{~kg} \mathrm{~d}^{-1}\right)$ in the buffaloes in Patan district of India. The findings of Chavda and Parnerkar (2016) are supported by the observations of Patange et al., (2002) and Singh et al., (2003) indicating a surplus of TDN supply. However, deficit supply of TDN in lactating buffaloes was also reported by Chaturvedi et al., (2009) and Singh et al., (2008) in their study.

Table 7. Deficit (-) and surplus (+) of DCP and TDN in lactating buffaloes in different agro-climatic zone in Bangladesh

\begin{tabular}{c|c|c|c|c|c|c}
\hline Areas & $\begin{array}{c}\text { Total } \\
\text { requirement } \\
\text { of DCP (g) }\end{array}$ & $\begin{array}{c}\text { Total } \\
\text { supply of } \\
\text { DCP (g) }\end{array}$ & $\begin{array}{c}\text { Deficit (-) } \\
\text { /surplus (+) } \\
\text { of DCP }\end{array}$ & $\begin{array}{c}\text { TDN } \\
\text { requirement } \\
\left(\mathrm{kg} \mathrm{d}^{-1}\right)\end{array}$ & $\begin{array}{c}\text { TDN } \\
\text { supply } \\
\left(\mathrm{kg} \mathrm{d}^{-1}\right)\end{array}$ & $\begin{array}{c}\text { Deficit (-) } \\
/ \text { surplus (+) } \\
\text { of TDN } \\
\left(\mathrm{kg} \mathrm{d}^{-1}\right)\end{array}$ \\
\hline Coastal area & 697.000 & 364.790 & -332.210 & 6.770 & 6.416 & -0.353 \\
\hline
\end{tabular}




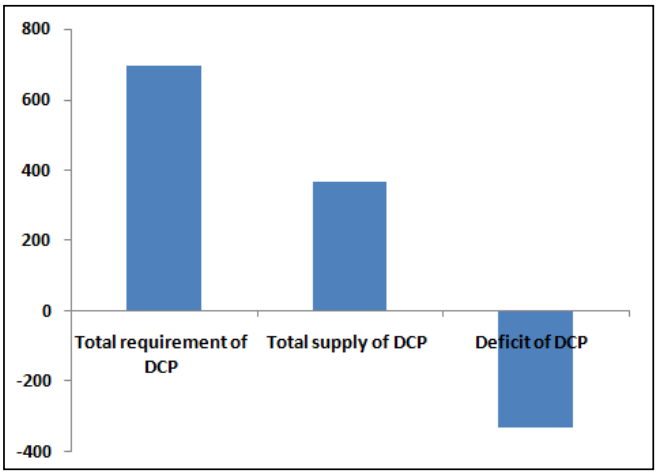

Figure 2. Total requirement and supply of DCP $\left(\mathrm{gm} \mathrm{d}^{-1}\right)$

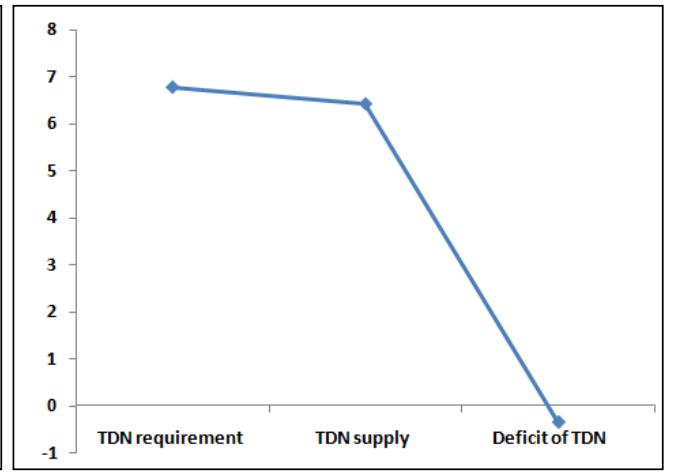

Figure 3. Total requirement and supply of TDN $\left(\mathrm{kg} \mathrm{d}^{-1}\right)$

\section{Productive and reproductive performance}

Productive and reproductive efficiency are influenced by different management system, nutrition and environment factors. A very low protein diet can cause cessation of oestrus (Agrawal, 2003). Though actual reproductive parameters is very difficult to find out without record or close supervision but farmer's experience would be asset for those information.

The average lactation length of indigenous buffalo cows were 197 days under semiintensive system in the study area (Table 8) which was low as compare to Karim et al., (2013); Faruque and Amin (1995). It might be happen for week management practice of the farmers as this system newly introduced in upper land in Bhola. Karim et al., (2013) found 286 days of lactation period in similar kind of buffaloes under extensive production system in Mathbaria and Pirozpur, which was 290 days in Pathorghata and Barguna. Faruque and Amin (1995) also reported that the lactation yield of indigenous buffalo in Khulna region were 280 liters. The findings of this study were also less similar to the findings of other authors (Bezerra et al., 2014; EIKirabi1995). The average milk yield $\left(\mathrm{L} \mathrm{d}^{-1}\right)$ and lactation yield ( $\mathrm{L} \mathrm{lactation}^{-1}$ ) were found as $2.39 \pm 0.83$ and $469.52 \pm 163.71$, respectively (Table 8 ). The average dry period (day), weaning age (day), service per conception (Number), age at first pregnancy (month), age at first caving (month), calving interval (month), gestation period (month), post partum heat period (month) were 42.80 $\pm 26.44,201.88 \pm 77.63$, $1.11 \pm 0.32, \quad 35.37 \pm 9.44, \quad 46.56 \pm 6.80, \quad 14.21 \pm 2.09, \quad 10.04 \pm 0.23$ and $3.94 \pm 1.51$, respectively (Table 8 ). Similar findings were also reported by other authors (Karim et al., 2013; Shabede et al., 2003). 
Table 8. Productive and reproductive trait of lactating buffalo under semi-intensive system

\begin{tabular}{l|l|l|l|l}
\hline \multicolumn{1}{c|}{ Parameters } & Mean \pm SD & Minimum & Maximum & $\begin{array}{c}\text { Highest } \\
\text { frequency } \\
\text { percentage }\end{array}$ \\
\hline Lactation Length (d) & $197.44 \pm 29.06$ & 150 & 270 & $180(37 \%)$ \\
Milk yield $\left(\mathrm{L} \mathrm{d}^{-1}\right)$ & $2.39 \pm 0.83$ & 1 & 5 & $2.3(18.2 \%)$ \\
Lactation yield (L lactation $\left.{ }^{-1}\right)$ & $469.52 \pm 163.71$ & 196 & 916 & $392(15 \%)$ \\
$\begin{array}{l}\text { Dry Period (d) } \\
\text { Weaning age(d) }\end{array}$ & $42.80 \pm 26.44$ & 30 & 90 & $30(60 \%)$ \\
$\begin{array}{l}\text { Service Per Conception } \\
\text { (Number) }\end{array}$ & $1.11 \pm 0.32$ & 1 & 2 & $180(24 \%)$ \\
$\begin{array}{l}\text { Age at first Pregnancy } \\
\text { (month) }\end{array}$ & $35.37 \pm 9.44$ & 33 & 48 & $34(34 \%)$ \\
$\begin{array}{l}\text { Age at first caving(month) } \\
\text { Calving interval (month) }\end{array}$ & $46.56 \pm 6.80$ & 34 & 58 & $46(28 \%)$ \\
$\begin{array}{l}\text { Gestation period (month) } \\
\begin{array}{l}\text { Post Partum heat period } \\
\text { (month) }\end{array}\end{array}$ & $14.21 \pm 2.09$ & 11 & 18 & $16(15.4 \%)$ \\
\hline
\end{tabular}

L, liter; d, day.

\section{Milk composition}

Milk composition of indigenous lactating buffalo under semi-intensive system is shown in Table 9. Milk composition attributed for breed, physiology of animal, environment, and management system (Ravikala et al., 2014). Nahar et al., (2014) found different milk composition of buffalo, though those were little lower or higher for different selected areas of Bangladesh. The average fat percentage of buffalo milk from Noakhali (8.16), Sirajgang (7.54), Potuakhali (7.18) and Bagerhat (6.92) (Nahar et al., 2014) which was similar value of fat $\%$ of our present study (7.30). The range of protein, lactose and SNF percentage were 3.00-4.36, 3.64-4.8 and 7.52-9.35 respectively. $\mathrm{EC}\left(\mathrm{ms} \mathrm{cm}^{-1}\right)$ value for present study was shown as $2.73 \pm 3.53$ with the range of $2.00-3.53 \mathrm{mS} \mathrm{cm}^{-1}$. Fahmid et.al., (2016) observed that EC value had less than $5.5 \mathrm{mS} \mathrm{cm}^{-1}$ which considered as healthy milk production. 
Table 9. Milk composition of lactating buffalo under semi-intensive system

\begin{tabular}{lccc}
\hline Variables & Mean $\pm \mathrm{SD}(\mathrm{N}=15)$ & Minimum & Maximum \\
\hline $\mathrm{TS}(\%)$ & $15.60 \pm 2.55$ & 12.81 & 19.63 \\
Fat $(\%)$ & $7.30 \pm 2.66$ & 4.07 & 11.97 \\
$\mathrm{SNF}(\%)$ & $8.30 \pm 0.54$ & 7.52 & 9.35 \\
Lactose(\%) & $4.03 \pm 0.32$ & 3.64 & 4.8 \\
Ash(\%) & $0.62 \pm 0.06$ & 0.53 & 0.75 \\
Protein(\%) & $3.64 \pm 0.41$ & 3.00 & 4.36 \\
$\begin{array}{l}\text { Electric conductivity (EC) } \\
\left.(\mathrm{mS} \mathrm{cm})^{-1}\right)\end{array}$ & $2.73 \pm 3.53$ & 2.00 & 3.53 \\
\hline
\end{tabular}

\section{Marketing}

All of the farmers sold milk to Ghosh. About 57.89 percent farmers received advance money (BDT3000-10000) on monthly basis from the Ghosh and 42.11 percent farmer didn't receive the same. The higher milk selling price was BDT 55.71 \pm 5.34 for the farmer who didn't take advance from Ghosh but selling price was relatively low (BDT 52.72 \pm 4.10 ) who had taken advance (Table 10). It also noted that milk market was more volatile in case of the farmers who didn't take advance from Ghosh as CV\% was higher (9.59\%) than other $(7.77 \%)$. The present finding is in agreement with the earlier findings of (Raha, 2010) who reported that price of milk was set below by BDT 5 liter $^{-1}$ in the case of advance payment.

Table 10. Milk marketing scenario in Bhola district (USD1=BDT78)

\begin{tabular}{l|c|c|c|c|c}
\hline \multicolumn{1}{c|}{ Group } & $\begin{array}{c}\text { \% of } \\
\text { farmers }\end{array}$ & $\begin{array}{c}\text { Amount of } \\
\text { advance } \\
\text { money (BDT } \\
\text { Month } \\
\text { Min-Max }^{-1}\end{array}$ & $\begin{array}{c}\text { Average milk } \\
\text { price } \\
\left(\text { BDT L }^{-1}\right)\end{array}$ & $\begin{array}{c}\text { SD } \\
\text { value }\end{array}$ & CV\% \\
\hline $\begin{array}{l}\text { Farmers who taken } \\
\text { advance }\end{array}$ & 57.89 & $3000-10000$ & 52.72 & 4.10 & 7.77 \\
$\begin{array}{l}\text { Farmers who didn't } \\
\text { taken advance }\end{array}$ & 42.11 & - & 55.71 & 5.34 & 9.59 \\
Overall & 100 & & & & \\
\hline
\end{tabular}


S.M.R. Rahman et al.

\section{Technology adaptation}

Adaptation levels of technologies for dairy buffalo farmers were very poor due to lack of public awareness and inadequate knowledge about buffalo husbandry (habitat, feeding, breeding \& health care). Only $17.4 \%$ farmer adopted for providing concentrate feed to their animal. Adaptation level of technologies e.g. use of ureamolasses straw/blocks, cultivation of fodder crops, use of Artificial Insemination(AI), practice for de-worming, practice for vaccination and provide vitamin-mineral premix from farmers were $0,0,4.3,8.7,0$ and $8.7 \%$, respectively. Average adaptation capacity of technologies were $16.34,11.53,12.01,13.4623 .07,17.30$ and $6.25 \%$ for use of urea-molasses straw/blocks, cultivation of fodder crops, use for AI, practice for de-worming, practice for vaccination and provide vitamin-mineral premix from farmers, respectively. Among those technologies, the capacity of technology was higher for practise of de-worming and vaccination though those were not followed regularly (Table 11). Creation of public awareness by different media; i.e. Radio, TV, Internet, Newspaper about the impotence of buffalo milk and meat as well as the good practice of dairy buffalo management might be improved the adaptation level of technologies.

Table 11. Technology adaptation of dairy buffalo farmers

\begin{tabular}{|c|c|c|c|c|}
\hline \multirow[t]{2}{*}{ Technical intervention } & \multicolumn{3}{|c|}{ Level of adaptation(Frequency) } & \multirow{2}{*}{$\begin{array}{l}\text { Average } \\
\text { capacity(index } \\
\text { ) of technology }\end{array}$} \\
\hline & Never & $\begin{array}{l}\text { Tried but } \\
\text { not adopt }\end{array}$ & $\begin{array}{l}\text { Fully } \\
\text { adopted }\end{array}$ & \\
\hline Provide concentrate feed & 69.6 & 13 & 17.4 & 16.34 \\
\hline Use of urea-molasses straw/blocks & 95.7 & 4.3 & - & 11.53 \\
\hline Cultivation of fodder crops & 91.3 & 8.7 & - & 12.01 \\
\hline Use for Artificial Insemination & 82.6 & 13 & 4.3 & 13.46 \\
\hline Practice for de-worming & - & 91.3 & 8.7 & 23.07 \\
\hline Practice for vaccination & 34.8 & 65.2 & - & 17.30 \\
\hline Provide vitamin-mineral premix & 52.2 & 39.1 & 8.7 & 6.25 \\
\hline
\end{tabular}

\section{Breeding}

Recently government buffalo project has started AI in Bhola district, but it is not popular because of insufficient AI worker as well as unavailable of buffalo semen and low conception rate. Farmers didn't get AI worker in right time when buffaloes showed heat. Traditionally farmers kept buffalo bull to bred buffalo cows in these areas. It means that there were two breeding systems in Bhola district. A total of 
95.7\% buffalo cow received natural breeding whereas AI covered only $4.3 \%$ of buffalo cows. Akbar et al., (2009) reported that the sufficient number of breeding bull was kept by the farmer in coastal areas and there were no fertility problem. However, inbreeding and abortion due to use same bull was common. They also noted that low oestrous detection (i.e. 30\%) was a major challenge that limited efficiency of AI use. According to farmer's observation, buffalo cows showed heat in different time. A few number of buffalo cows $(4.2-5.2 \%)$ showed heat in day time but higher number of the buffalo cows showed heat in early morning (54.2\%), followed to early night $(22.2 \%)$ and late night $(9.3 \%)$ (Table 12). Saadullah, (2012) stated that the buffaloes showed their maximum activity during the night and breeding take place mainly during night. Therefore present study has been supported to the information of Saadullah, (2012) though a few number of buffalo cows showed heat in day time $(4.2-5.2 \%)$.

Table 12. Type of breeding and time of heat showed by buffalo cows

\begin{tabular}{l|l}
\hline Variable & Value \\
\hline Type of breeding & 95.7 \\
Natural breeding (\% of buffalo) & 4.3 \\
Artificial insemination (AI) (\% of buffalo) & \\
Time of showing heat & 54.2 \\
Morning (\% of buffalo) & 4.8 \\
Noon (\% of buffalo) & 5.2 \\
Afternoon (\% of buffalo) & 4.2 \\
Evening (\% of buffalo) & 22.2 \\
Early night (\% of buffalo) & 9.3 \\
Late night (\% of buffalo) & \\
\hline
\end{tabular}

\section{Hygienic measure for buffalo rearing}

Farmers kept manure near to the animal shed in small hole, situated from 2-20 feet distance from the shed. However sometime they did not make small hole and manure through the open places. A total of $22 \%$ farmers did not follow good practice for waste management. The udder health situation of milking buffaloes was aggravating as mastitis was rising as of the notification of farmers (7\%). Islam et al., (2016) isolated pathogens (i.e. Coagulase Negative Staphylococci (CNN), Staptococcus spp. and Bacillus spp. and Staphylococcus aureus) from milk sample in Bangladesh including coastal areas that were responsible for mastitis in lactating buffaloes. Only 
hand milking was followed practiced in the study areas. They washed their hands, milking pots and also cleaned milking parlour/platform before milking. All of the farmers allowed calves to suckle udder of buffalo by the calf for stimulating hormonal affects before starting milking.

\section{CONCLUSION}

The productive and reproductive performance of indigenous dairy buffalo was not better to high producing dairy buffalo's. Scientific management and improved breeding system could minimize this situation. Optimum use of feed resources and their treatment whenever needed becomes evident from the present study. Improved adaptation level of technologies would be ensured by creating public awareness and by providing door-step service to the buffalo farmers. It is therefore, can be concluded that technological transformation is important to boost up of the productivity of the dairy buffaloes under semi-intensive system.

\section{ACKNOWLEDGEMENT}

The authors are highly encouraged due to financial support from BAS-USDA. The authors also grateful to Coast Trust (a National NGO working at coastal areas) for supporting in the field.

\section{REFERENCES}

Agrawal, K.P. (2003). Augmentation of reproduction in buffaloes. Proceedings of 4th Asian Buffalo Congress, New Delhi, India: 121.

Akbar, M.A., Faruque, M.O., and Islam, M.N. (2009).Current dairy feeding and management systems: Dairy buffaloes. In. Hand Book of Dairy Nutrition-Bangladesh [Published by American Soybean Association: International Marketing, edited by Peter H. Robinson and U. Krisnamorthy], New Dilhi, India. 50-64.

Amin, M.R., Siddiki, M.A., Kabir, A.K.M.A., Faruque, M.O., and Khandaker, Z.H. (2015). Status of buffalo farmer and buffaloes at Subornochar upozila of Noakhali District. ProgressiveAgriculture,26(1),71-78.

https://www.banglajol.info/index.php/PA/article/view/24519

Bakshi, M.P.S., Wadhwa, M., and Hundal, J.S.(2010). Nutritional status of animals in periurban dairy complexes in Punjab, India. Indian Journal of Animal Science, 80: 745-749. https://www.researchgate.net/.../301274618

Bezerra, J. Da. S., Fraga A.B., Couto, A.De.G., Barros, C.Da.C., and Silva, R.M.de.O. (2014). Milk production, lactation length and calving interval in crossbreds of murrah buffalo cows. Revista-Caatinga. 27(2) 184-191. https://www.researchgate.net/publication/ 286827790

Bilal, M.Q., Suleman, M., and Raziq, A. (2006). Buffalo: Black gold of Pakistan. Livestock Research for Rural Development, 18(9),2006. https://www.researchgate.net/ publication/268055348 
Chaturvedi, O.H., Mann, J.S., and Verma D.L. (2009). Feeding practices and nutritional status of Lactating buffaloes at farmer's field in semi arid region-A case study. Indian Journal of Animal Nutrition 26, 265-268.

Chavda, M.R., and Parnerkar, S. (2016). Nutritional status of buffaloes in Patan district of North Gujrat. International Journal of Science, Environment and Technology, Vol. 5, No 6, 2016, 4173 - 4178. https:// www.ijset.net/journal/1432.pdf

Dhanda, O.P. (2013). Changing Dynamics in Buffalo Production Systems in South Asian Region. Buffalo Bulletin,Vol.32 (Special Issue 1): 311-317. http://ibic.lib.ku.ac.th/eBulletin/IBBUSI201301027.pdf

DLS. (2017). Directorate of Livestock Service. Souvenir Livestock Service Week. 23-27 February 2017.

DLS. (2018). Directorate of Livestock Service. Livestock Economy at a Glance, Ministry of Fisheries and Livestock. http://www.dls.gov.bd/site/page/22b1143b-9323-44f8-bfd8647087828c9b/Livestock-Economy;Visited 03 December 2018.

EI-Kirabi,. E. (1995). Buffalo population and production in Egypt. Buffalo Newsletter, 38.

Fahmid, S., Hassan, E., Naeem, H., Barrech, S., Lodhi, S. and Latif, S. (2016). Determination of mastitis by measuring milk electrical conductivity. International Journal Advance Research Biological Science, 3(10), 1-4. http://dx.doi.org/10.22192/ijarbs.2016. 03.10 .001

Faruque, M.O. (2000). Final report of the project-Identification of best genotype of buffalo for dairy purpose in Bangladesh and to improve their productivity. Paper presented at a seminar in Bangladesh Agricultural Research Council. Dhaka.

Faruque, M.O., and Amin, M.R. (1995). Indigenous buffaloes in the coastal area of Bangladesh: part-II. Productivity of indigenous buffaloes in the south western coastal area. Bangladesh Journal Training and Development, 4, 138-140.

Feedipedia, (2018). An on-line encyclopedia of animal feeds. Feedipedia https://www.feedipedia.org/

FAO. (2010). Food and Agricultural Organization of United Nations. Production Year book 2008, FAO, Rome, Italy.

Hamid, M.A., Ahmed, S., Rahman, M.A., and Hossain, K.M. (2016). Status of Buffalo Production in Bangladesh Compared to SAARC Countries. Asian Journal of Animal Science, 10 (6): 313-329, https://scialert.net/abstract/ doi=ajas.2016.313.329

Habib, G., Hameed, A., and Akmal, M. (2007). Current feeding management of peri urban dairy buffaloes and scope for improvement. Pakistan Veterinary Journal, 27(1), 3541. https://www.researchgate.net/publication/242160683

Huque, K.S., and Khan, M.Y.A. (2017). Socio-geographic distribution of livestock and poultry in Bangladesh-a review. Bangladesh Journal Animal Science, 46 (1), 65-81. https://www.banglajol.info/index.php/BJAS/.../32180

Huque, Q.M.E., and Borghese, A. (2013). Status and Perspectives of Buffalo in Bangladesh. Buffalo Bulletin,Vol.32 (Special Issue 2), 1179-1183. http://ibic.lib.ku.ac.th/eBulletin/IBBUSI201302216.pdf 
Islam, K.B.M. S., Kabir, M.H.B., Rahman, M.H., and Kabir, M.H. (2016). Status of buffalo disease in Bangladesh in relation to casual agents and predisposing factors. International Journal of Livestock Science and Technology, 9(5),44-50. https://www.researchgate.net/publication/308417683

Islam, M.R., Hasanuzzaman, M., Jalil, M.A., and Huque, K.S. (2002). Identification, screening and nutritive value of forages available throughout Bangladesh. Animal Production Research Division, Bangladesh Livestock Research Institute, Savar, Dhaka 1341, Bangladesh.

Jawale, M.R., Kank, V.D., Patil, M.B., Chopde, S.V., Jagadale, C., and Karambele, N.R. (2007). Nutritional status of dairy animals from Pune district of Maharastra. In: Proceeding of International Tropical Animal Nutrition Conference,National Dairy Research Institute, Karnal, India, October 4-7, 2007. pp.69.

Kearl, L.C. (1982). Nutrient requirements of ruminants in developing countries. International Feedstuffs Institutes. Utah Agricultural Experiment Station. Utah State University, Logan Utah.

Muhammad Subhan Qureshi (2009). Research article, Nutritional and management support to reproduction in dairy buffaloes under tropical conditions-research gate. http://www.researchgate.net/publication/210268838_Nutritional_and_Management_Su pport_to_Reproduction_in_dairy_Buffaloes_Under_Tropical_Conditions. Accessed on May 27, 2015.

Nahar, T.N. (2015). Study on the productive and reproductive efficiency of native buffalo. Detail report. Computer \& GIS Unit, BARC. Dhaka, 11, Bangladesh (unpublished data).

Nahar, T.N., Rahman, M.M., and Islam, M.S. (2015). Study on availability, present production, and utilization system of different feeds and fodder in selected regions. Proceeding of the annual research review workshop,2013-2014,Bangladesh Livestock Research Institute, Savar, Dhaka1341.

Nahar, T.N., Alam, M.K., and Akhtar, S. (2014). Study the assessment of nutritional composition and bacterial load in buffalo milk in some selected areas of Bangladesh. Proceeding of the Annual Research Review Workshop, 2012-13.Bangladesh Livestock Research Institute, Savar, Dhaka 1341.

Patange, D,D., Kulkarni, A.N., Gujar, B.V., and Kalyanrkar, S.D. (2002). Nutrient availability to milch Marathwadi buffaloes in their home tract. Indian Journal of Animal Nutrition, 19,41-46.

Raha, S.K. (2010). Value Chain Development for Dairy (Cow and Buffalo) Production in coastal region. Research Report of Microfinance and Technical Support Project, PalliKarma-Sahayak Foundation (PKSF),Dhaka, Bangladesh,(unpublished data).

Rai, S.N., and Aggarwal., S.K. (1991). Effect of substitution of green fodder with ammoniated straw on nutrient utilization and milk production in Murrah buffaloes. Buffalo Journal,1,51-61.

Ranjhan, S.K. (1991). Chemical Composition of Indian Feeds and Feeding of Farm Animals. 6th new edition ICAR, New Delhi. 
Ravikala, K., Patbandha, T.K., and Vataliya, P.H. (2014). Nutritional management of dairy animals through milk yield and its component evaluation. Proceeding of 21st annual convention of Indian Society of Animal Production and Management, January 28-30, 2014, AAU, Anand, Gujarat, India. pp. 137-144.

Saadullah, M. (2012). Buffalo production and constants in Bangladesh. Journal of Animal and Plant Science, 22(3 Supplement), 221-224.

Sarkar, S., Hossain, M.M., and Amin, M.R. (2013). Socio-economic status of buffalo farmer and the management practices of buffaloes in selected areas of Bagerhat District of Bangladesh. Bangladesh Journal Animal Science,42(2),158-164. http://dx.doi.org/ 10.3329/bjas.v42i2.18505

Sen, K.C., and Ray, S.N. (1978). Nutritive value of Indian feeds and fodders. Published No.25, Indian Council of Agricultural Research, New Delhi.

Shabade, N.S., Jagtap, D.Z., and Behle, N.D. (1993). Factors affecting production and production efficiency traits of first lactation Murrah buffaloes. Indian Journal Animal Science, 63(11), 1212-1213.

Shamsuddin, M., Bhuiyan, M.M.U., Sikder, T.K., Sugulle, A.H., Chanda P.K., Galloway, D., and Alam, M.G.S. (2001). Constraints limiting the efficiency of artificial insemination of cattle in Bangladesh. IAEA,TECHDOC 1220, 9 -27.

Siddiki, M.A. (2017). Improvement of production potential of buffaloes supplemented with protein and energy based diets. PhD thesis, Department of animal science, Bangladesh Agricultural University, Mymensingh.

Singh, C.B., Pramanik, P.S., and Mishra, S. (2003). Availability of nutrients from prevailing feeds and fodders to dairy animals in eastern plain zone of Uttar Pradesh. Indian Veterinary Medicine Journal, 27, 53-54.

Singh, V.K., Singh, P., Verma, A.K., and Mehra, U.R. (2008). On farm assessment of nutritional status of lactating cattle and buffaloes in urban, periurban and rural areas of Middle Gangetic Plains. Livestock Research for Rural Development, 20 (8) 2008, http://www.lrrd.org/lrrd20/8/singh20130.htm

Uddin, M.K., Mintoo, A.A., Awal, T.M., Kondo, M., and Kabir., A.K.M.A. (2016). Characterization of buffalo milk production system in Bangladesh. Bangladesh Journal of Animal Science, 45 (1), 69-77 https://www.banglajol.info/index.php/ BJAS/article/view/27492

Vidya, S., Anand, R.K., and Dwivedi, S.V. (2013). Nutritional status and reproductive performance of dairy cattle and buffaloes in Sonbhadra district of Uttar Pradesh. International Journal of Science and Nature, 4, 494-498. http://www.scienceandn ature.org/IJSN_Vol4(3)S2013/IJSN-VOL4(3)13-21

Wikipedia. (2017). Bangladesh map of Köppen climate classification. Available on https://upload.wikimedia.org/wikipedia/commons/9/94/Bangladesh_map_of_K\%C3\% B6ppen_climate_classification.svg. 20/11/2017. 15.44 PM. 